\title{
Sports injuries in an accident and emergency department
}

\author{
D. A. K. WATTERS*,S. BROOKS $\dagger$, R. A. ELTON $\ddagger$ \\ and K. LITTLE $\S$
}

* Department of Accident and Emergency Medicine, King Edward VII Hospital, Durban, South Africa; $\dagger$ Department of Accident and Emergency Medicine, Kent and Canterbury Hospital, Canterbury; $\ddagger$ Department of Medical Computing and Statistics, Medical School, Edinburgh; § Department of Accident and Emergency Medicine, Royal Infirmary, Edinburgh

\section{SUMMARY}

Over a one year period, 2270 sports injuries were seen in the Accident and Emergency Department at the Royal Infirmary, Edinburgh. This represented $3.9 \%$ of the total new patients seen in that year. Football and rugby were the most frequent sports responsible for injury. Seventy-eight per cent of injured persons were 26 or under and $88.7 \%$ of injuries occurred in men. The two months with the most sports injuries were September and February; $74 \%$ (1683) patients stated they trained at least once a week and $85 \%$ (1895) played the sport in which they were injured at least once a week. Players who did not train were less likely to incur a severe injury than those who did. Fourteen per cent of the injuries were the result of foul play, but again foul play was less likely to cause a serious injury; $41 \%$ of injuries were to the lower limb; $45 \%$ of injuries were fractures, dislocations, lacerations and head injuries; $7 \%$ of patients required admission to hospital and $22 \%$ were referred to a clinic. Seventy-seven per cent of the referrals were to the orthopaedic department. The relevance of these figures to the accident and emergency workload is discussed.

\section{INTRODUCTION}

Participation in sport is generally assumed to be beneficial to health. Inevitably, however, sports men and women risk injury and in recent years the importance of sports medicine has been recognised and sports injury clinics have been initiated. Many sports injury clinics do not offer emergency services and some only cater for top class competitors so that the majority of injuries occurring in organised sport still present

Correspondence: $\operatorname{Dr}$ K. Little, Department of Accident and Emergency Medicine, Royal Infirmary, Edinburgh EH3 $9 Y W$ 
first of all to the accident and emergency department. The aim of this prospective study was to assess the proportion of referrals to the accident and emergency department due to injuries incurred whilst participating in sport, and to note which sports and which injuries occured. Since it is often assumed that training protects against injury, al patients with sports injuries were questioned about their training.

\section{METHODS}

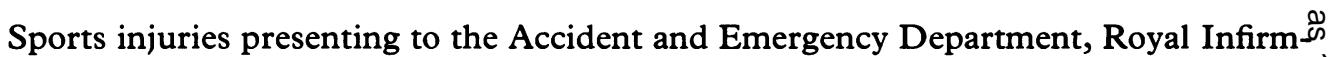
ary of Edinburgh were prospectively studied over a one year period from 1 Aprip 1980-31 March 1981. Only injuries occurring in organised sports were included. On $\vec{\sharp}$ standard proforma the patient's age, sex and sport responsible for the injury were recorded together with the date of the injury and the frequency with which the patien $\underline{B}$. both trained and played this sport and any other. Patients who trained once a week or more were considered to train regularly and the same definition was taken for the frequency of participation in the sport itself. The relationship of the injury to foul playe or defective clothing or equipment was recorded. The site and nature of the injury, the treatment received in the accident and emergency department and disposal were noted but the patient was not followed up beyond his initial attendance in this study. All this data was computerised to simplify the presentation of results as frequency tables and percentages. Cross tabulation was performed to compare two variables such as trainingoo and type of injury.

\section{RESULTS}

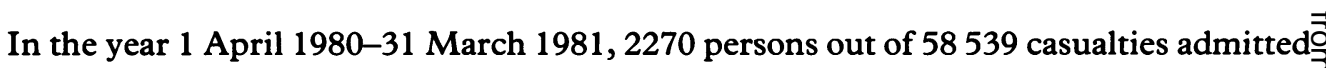
that their injury had occurred as a result of participation in organised sport. The sports responsible are shown in Tables 1 and 2.

\section{Age distribution and sex}

Fifty-two per cent of injuries occurred in those 21 or under and $78 \%$ in those aged 26 orô under. Eighty-seven per cent in those under 30 and $97 \%$ in those under 40 . The age range in this series was from 9-74 with a mean age of $22 \cdot 2 \pm 6 \cdot 6$ years. The mean age for 9 sportsmen was $22 \cdot 16 \pm 6.59$ and for sportswomen $20 \cdot 9 \pm 7 \cdot 5 ; 2015$ injuries occurred in men and 255 in women.

\section{Seasonal variation}

Table 3 shows the number of sports injuries presenting to the department month by? month. There were less injuries in the holiday periods; December-January and? May-August. This trend is not reflected in the total number of patients presenting to $\stackrel{\oplus}{\rightarrow}$ the department in these months. 
Table 1 Sport responsible for injury and mean age in all patients

\begin{tabular}{lccc}
\hline Sport & $\begin{array}{c}\text { Number of } \\
\text { injuries }\end{array}$ & Percentage & Mean age \pm SD \\
\hline Football & 932 & 41 & $22 \cdot 5 \pm 6 \cdot 3$ \\
Rugby union & 520 & 23 & $20 \cdot 8 \pm 6 \cdot 0$ \\
Skiing & 163 & 7 & $22 \cdot 7 \pm 8 \cdot 7$ \\
Hockey & 84 & 4 & $19 \cdot 8 \pm 7 \cdot 1$ \\
Squash & 82 & 4 & $28 \cdot 1 \pm 6 \cdot 9$ \\
Basketball & 70 & 3 & $18 \cdot 6 \pm 5 \cdot 5$ \\
Karate & 59 & 3 & $22 \cdot 5 \pm 5 \cdot 1$ \\
Judo & 45 & 2 & $18 \cdot 6 \pm 5 \cdot 5$ \\
Badminton & 43 & 2 & $28 \cdot 7 \pm 11 \cdot 3$ \\
Cricket & 33 & 1 & $28 \cdot 6 \pm 9 \cdot 5$ \\
Horse riding & 31 & 1 & $24 \cdot 4 \pm 10 \cdot 6$ \\
Volleyball & 23 & 1 & \\
Boxing & 20 & 1 & \\
Tennis & 17 & 1 & \\
Athletics & 16 & 1 & \\
Jogging & 14 & 1 & \\
Gymnastics & 14 & 1 & \\
Golf & 10 & $0 \cdot 5$ & \\
Others & 94 & 4 & \\
& & & \\
\hline
\end{tabular}

Table 2 Female sports injuries (255)-sports responsible

\begin{tabular}{lcc}
\hline Sport & Number & Percentage \\
\hline Skiing & 61 & 24 \\
Hockey & 43 & 17 \\
Horse riding & 25 & 10 \\
Basketball & 22 & 9 \\
Badminton & 18 & 7 \\
Volleyball & 12 & 5 \\
Squash & 9 & 4 \\
Gymnastics & 8 & 3 \\
Athletics & 6 & 2 \\
Karate & 5 & 2 \\
Judo & 5 & 2 \\
Others & 41 & 16 \\
\hline
\end{tabular}

Table 3 Seasonal variation of number of sports injuries

\begin{tabular}{lllll}
\hline January & $171(5023)$ & May & $163(4932)$ & September 254(4899) \\
February & $277(4462)$ & June & $144(4798)$ & October 214 (4869) \\
March & $205(5057)$ & July & $103(4757)$ & November 221 (4805) \\
April & $223(4827)$ & August $143(5365)$ & December 152 (4745)
\end{tabular}

Figures in brackets are total referrals to accident and emergency department for that month 


\section{Training}

Seventy four per cent (1683) patients claimed they trained once a week or more and $85 \%$ (1895) claimed they played at least once a week. Thus the vast majority of injurie occurred in reasonably fit individuals accustomed to the rigors of their sport. Cross tabulation of training and regular participation against severity of injury failed to $\frac{0}{8}$ demonstrate any difference in the severity of the injury received by those who trained of played regularly and those who did not.

\section{Foul Play}

Fourteen per cent (327) of the injuries were said to have occurred as a result of foul play $\overrightarrow{\vec{\omega}}$ Twenty-four perr cent of footballing injuries were due to foul play compared with onlȳ $9 \%$ of rugby injuries. Foul play was less likely to result in a serious injury when cros? tabulation displays of foul play against type of injury were examined.

\section{Site and type of injury}

The site and type of injury are shown in Tables 4 and 5. The lower limb was the site of injury in $41 \%$ of patients, followed by the upper limb (34\%) and head and neck $(16 \%)^{\infty}$ When these figures are broken down more specifically it is found that the ankle $(19 \%$ and hand $(17 \%)$ were the parts most frequently injured. The majority of injuries cotid be classed as soft tissue sprains and strains $(55 \%)$, but $45 \%$ of the injuries wo fractures, dislocations, lacerations and head injuries. Thus injury in sport is inconsequential.

Table 4 The site of injury in 2270 sports injuries

\begin{tabular}{lrr}
\hline Head and neck & 363 & $16 \%$ \\
Upper limb & 763 & $34 \%$ \\
Shoulder & 147 & $7 \%$ \\
Arm and wrist & 229 & $10 \%$ \\
Hand & 387 & $17 \%$ \\
Trunk & 83 & $4 \%$ \\
Lower Limb & 935 & $41 \%$ \\
Hip and thigh & 32 & $1 \%$ \\
Knee & 214 & $10 \%$ \\
Calf & 110 & $5 \%$ \\
Ankle & 417 & $19 \%$ \\
Foot & 162 & $7 \%$ \\
\hline
\end{tabular}

Table 5 Type of injury in 2270 sports injuries

\begin{tabular}{|c|c|c|}
\hline Soft tissue & 1256 & $55 \%$ \\
\hline Laceration & 222 & $10 \%$ \\
\hline Fracture & 533 & $23 \%$ \\
\hline Dislocation & 75 & $3 \%$ \\
\hline Head injury & 57 & $3 \%$ \\
\hline Ligament/cartilage tear & 71 & $3 \%$ \\
\hline Others & 24 & $1 \%$ \\
\hline Effusion & 21 & \\
\hline CVS & 1 & \\
\hline Urological & 1 & \\
\hline Psychiatric & 1 & \\
\hline
\end{tabular}

\section{Treatment and disposal}

Eight-four per cent (1906) patients had one or more radiographs taken. The broad categories of treatment given are shown in Table 6. Sixty-four per cent were advise 
and discharged with or without symptomatic treatment such as pain killers, elastocrepe bandage, elastoplast dressings, $36 \%$ required more active treatment in the form of suturing, plastering, reduction of fractures and dislocations, antibiotics, aspiration, nail trephining or splintage.

Table 7 shows the disposal of the patients; $36 \%$ required to be followed up and $7 \%$ required admission; $6 \%$ were reviewed by the accident and emergency department; $8 \%$ were sent home to be followed up by their GP and $22 \%$ were referred to other hospital clinics. The department responsible for further management of those who were referred to clinics or admitted is shown in Table 8. Seventy-seven per cent of the 677 patients were subsequently reviewed by the orthopaedic department.

Table 6 Treatment received in accident and emergency department in 2270 sports injuries

\begin{tabular}{lrr}
\hline Advice, symptomatic treatment & & \\
$\quad$ and discharge & 1457 & $64 \%$ \\
Suture/steristrip & 208 & $9 \%$ \\
Plaster of paris \pm reduction & 159 & $7 \%$ \\
Support/splintage & 234 & $10 \%$ \\
Referral without treatment & 181 & $8 \%$ \\
Others & 28 & $1 \%$ \\
\hline
\end{tabular}

Table 7 Disposal

\begin{tabular}{lrr}
\hline No follow up & 1266 & $57 \%$ \\
G.P. & 172 & $8 \%$ \\
A \& E follow up & 132 & $6 \%$ \\
O.P. clinic & 505 & $22 \%$ \\
Admission & 163 & $7 \%$ \\
\hline
\end{tabular}

Table 8 Department involved in follow up

\begin{tabular}{lrr}
\hline Orthopaedic & 520 & $77 \%$ \\
E.N.T. & 77 & $11 \%$ \\
Neurosurgery & 45 & $7 \%$ \\
Oral surgery & 20 & $3 \%$ \\
General surgery & 6 & $1 \%$ \\
Medical & 2 & - \\
Urology & 2 & - \\
Cardiothoracic & 1 & - \\
\hline
\end{tabular}

\section{DISCUSSION}

There are a number of limitations in a prospective study of this nature. We have only categorised sports injuries which presented to this department. In the city of Edinburgh there are two smaller accident and emergency departments which will also have seen and treated sports injuries. There is also a separate $24 \mathrm{~h}$ eye accident and emergency service and therefore eye injuries are generally excluded from this survey. Children up to the age of thirteen are usually seen in the children's hospital so that injuries occurring in children's sport are also not included. We must also accept that we do not know how many people participate in the various sports available in the Edinburgh area and therefore we can make no assessment of the risk of incurring an injury in a particular sport. Others have attempted to do this for some sports particularly rugby (Walkden, 1975; Weightman \& Browne 1974, 1975; Durkin, 1977; Sparks, 1981) but these were 
club doctors who were able to accurately. assess the number of injuries/player hou occurring in their club. A survey of sports injuries presenting to an accident ared emergency department is a survey of those injuries which appear serious enough warrant referral (either by the patient himself or the club doctor) and which then arrive at the chosen accident and emergency department.

Crompton \& Tubbs (1977) made a retrospective survey of sports injuries presentirig to the Birmingham Accident Hospital. Their gross figures are similar to ours in that 40169 casualties, $2809(7 \%)$ were injured whilst participating in sport. It might. $\mathrm{S}^{\mathrm{E}}$ reasonable to suggest, therefore, that $4-7 \%$ of the caseload in accident and emergenê. departments are the result of sports injuries. Eighty four per cent of our patients required radiographic investigation and $36 \%$ required specific treatment so that spor $\overrightarrow{8}$ injuries account for a small but significant proportion of an accident department $\overrightarrow{\vec{s}}$ workload. Little or no training in the treatment of sports injuries is given at unde? graduate or post graduate level and this should be rectified. The doctor examining an patient injured in sporting activity requires a greater understanding of the mechanics of that injury and a more ready understanding of the demands of the patient to return to his sporting activity. Simple conservative immobilisation of the injured part may doca great dis-service to the patient and to the injury. In a previous paper the benefits of immediate physiotherapy for the sprained ankle has been clearly demonstrated (Brooks et al.,1981).

The high incidence of injuries in Association Football and Rugby Union was expected. Weightman \& Browne $(1974,1975)$ estimated that injuries occur in football a rate of $36.5 / 10000$ man hours play and in rugby at a rate of 30.5/10000 man he̊gits play. Figures for other sports were lower, 10.3/10 000 man hours for men's hockey \&ne $1 \cdot 46 / 10000$ man hours for badminton. If our injury rates are assumed to be similar them 932 football injuries represent more than 250000 hours of play and 520 rugby injuris represent over 170000 hours of play, 84 hockey injuries (both men and women'\$) represent about 75000 and 43 badminton about 300000 hours. We have at present $\overrightarrow{\mathrm{B}} \overrightarrow{\mathrm{B}}$ way of checking these estimations in our area.

The seasonal distribution of injuries is to be expected from social patterns in the Edinburgh area. The two months with the highest number of sports injuries were February and September immediately following the period of lay-off in the majợ contact sports, namely rugby and football. This is confirmed when these two sports a looked at individually (Davies \& Gibson, 1978).

One striking fact in this study is the high number of injured participants who traine and played regularly. This may reflect greater opportunity for injury and since we dब not know the training and playing frequency of those who are not injured, we cannot comment on whether players are protected from injury by training although this seen likely and the seasonal figures suggest it. Certainly training did not in this prospective study appear to protect against severity of injury. These questions can only be resolvẹg at club level.

The site most frequently injured was the lower limb. The large injury contribution of football and rugby made this inevitable and others have reported the preponderance of lower limb injury in these sports (Weightman \& Browne, 1974). Particular attention should be paid to the training of accident and emergency doctors in the treatment of ankle injuries. It is inadequate to exclude a fracture and send the patient home whe 
dealing with a sportsman. The site of injury depends of course on the sport and analysis of the site and type of injury in any particular sport should alert one to preventative measures which can be employed. We hope to break down our figures for a number of the common sports in a future article.

Forty-four per cent of the patients required some form of follow up, $77 \%$ of those followed up in clinics being reviewed by the orthopaedic department ( $23 \%$ of all sports injuries). Much of the responsibility for sports injuries lies with the orthopaedic services. The 45 patients seen by the neurosurgical services represents a special head injury ward in Edinburgh run by the neurosurgical department. Only 24 patients were referred for physiotherapy which suggests that not enough use is being made of this service in those patients with soft tissue injuries (Brooks et al., 1981).

We would conclude that injuries sustained in sport make a considerable demand on the Accident and Emergency Services of the UK, in our experience this being 3.9\% of the total patients. The patients were in general, young and presumably in their productive working years and a much more aggressive therapeutic approach is almost certainly required. It would appear that the staff in this Teaching Hospital Department are lacking in understanding of the requirements of sportsmen and their soft tissue injuries and greater emphasis should be placed on the appropriate education in the undergraduate and postgraduate years. It would be possible to improve appreciation of the problems with special clinics to which sporting soft tissue injuries were referred and perhaps the introduction of such a clinic in the accident and emergency setting with appropriate physiotherapy backup would be the most beneficial step which can be taken to immediately rectify the problems in this difficult clinical area.

\section{REFERENCES}

Brooks S. C., Potter B. T. \& Rainey J. B. (1981) Treatment for partial tears of lateral ligament of the ankle-a prospective trial. British Medical fournal 282, 606-7.

Brooks S. C., Potter B. T. \& Rainey J. B. (1981) Inversion injuries of the ankle: clinical assessment and radiographic review. British Medical fournal 282, 607-8.

Crompton B. \& Tubbs N. (1977) A survey of sports injuries in Birmingham. British fournal of Sports Medicine 11, 12-5.

Davies J. E. \& Gibson T. (1978) Injury in Rugby Union Football. British Medical fournal 2, 1759-63.

Durkin T. E. (1977) A survey of injuries in a 1st class rugby union football club 1972-1975. British fournal of Sports Medicine 11, 7-11.

Sparks J. P. (1981) Half a million hours of rugby football-the injuries. British fournal of Sports Medicine 15, 30-2.

Walkden L. (1975) Medical hazards of rugby football. The Practitioner 215, 201-7.

Weightman D. \& Browne R. C. (1974) Injury in rugby and association football. British fournal of Sports Medicine 8, 183-7.

Weightman D. \& Browne R. C. (1975) Injury in eleven selected sports. British fournal of Sports Medicine 9, $136-41$. 